\title{
STRATEGI PENGEMBANGAN USAHA BERAS SEHAT PADA CV PURE CIANJUR DI KABUPATEN CIANJUR
}

\author{
Agrivinie Rainy $F^{1)}$, Rita Nurmalina ${ }^{2)}$ dan Amzul Rifin ${ }^{3)}$ \\ 1,2,3) Departemen Agribisnis, Fakultas Ekonomi dan Manajemen, Institut Pertanian Bogor \\ 1) agrivinierainyf@gmail.com
}

\begin{abstract}
The objectives of this research are to identify the factors that exist in the internal and external environment that become the strengths, weaknesses, threats, and opportunities for CV Pure Cianjur, formulate alternative strategies and determine the priority strategies that can be run $C V$ Pure Cianjur in developing business, mapping program recommendations from alternative strategies in the development of healthy rice business on CV Pure Cianjur. The method research use internal and eksternal environment analysis, formulation strategy using SWOT analysis, weighting strategy priorities through preparation of hierarchy based on the SWOT framework (A'WOT) and the program recommendation made by the strategic architecture model. Internal factors of company: strength $(S)$ is the quality of products $(0,377)$ and weaknesses factor $(W)$ is discontinuity of raw material supply $(0,402)$. External factors of company opportunities $(O)$ is the natural resources of Cianjur Regency $(0,181)$ and threats $(T)$ factors is the substitution products (anorganic rice) (0,349). Priority of strategic alternatives is conduct preparation and registration for organic certification (0,299). Implication of alternative strategies is devided into two groups, where is 11 programs recommendation that run gradually and 7 programs recommendation that run regularly.
\end{abstract}

Keyword(s): healthy rice, business development stragtegy, CV Pure Cianjur, A'WOT, alternatives strategy

\begin{abstract}
ABSTRAK
Penelitian ini bertujuan untuk mengidentifikasi faktor-faktor yang terdapat pada lingkungan internal dan eksternal yang menjadi kekuatan, kelemahan, peluang dan ancaman bagi CV Pure Cianjur, merumuskan alternatif strategi dan menentukan prioritas strategi yang dapat dijalankan oleh CV Pure Cianjur dalam mengembangkan usahanya, memetakan rekomendasi program dari alternatif strategi dalam pengembangan usaha beras sehat pada CV Pure Cianjur. Metode penelitian yang digunakan yaitu dengan menganalisis lingkungan internal dan eksternal pada perusahaan, merumuskan alterntif strategi menggunakan metode analisis SWOT, pemilihan prioritas alternatif strategi melalui penyusunan analisis proses hierarki dengan kerangka SWOT (A'WOT) dan rekomendasi program yang diperoleh melalui analisis arsitektur strategi. Kekuatan utama yang dimiliki perusahaan adalah produk yang berkualitas $(0,377)$ dan kelemahan utama yang dimiliki perusahaan adalah diskontinuitas pasokan bahan baku $(0,402)$. Peluang utama yang dimiliki oleh perusahaan adalah sumberdaya alam yang dimiliki Kabupaten Cianjur $(0,181)$, dan ancaman utama yang dimiliki oleh perusahaan adalah produk substitusi (beras anorganik) (0,349). Prioritas strategi yang diterapkan pada CV Pure Cianjur dalam mengembangkan usahanya adalah melakukan persiapan dan pendaftaran untuk mendapatkan sertifikasi organik $(0,299)$. Implementasi alternatif strategi dibagi dalam dua kelompok yaitu 11 rekomendasi program yang dijalankan secara bertahap dan 7 program kerja secara rutin.
\end{abstract}

Kata Kunci: beras sehat, strategi pengembangan, CV Pure Cianjur, A'WOT, arsitektur strategi 


\section{PENDAHULUAN}

Sektor pertanian merupakan sektor yang memiliki peranan penting dalam perekonomian Indonesia, salah satunya adalah sebagai penyedia bahan pangan bagi mayoritas penduduk Indonesia. Komoditas pangan merupakan kebutuhan yang paling mendasar dan pokok bagi suatu bangsa, termasuk Indonesia sehinga pangan dapat dikatakan sebagai kebutuhan hak asasi setiap manusia. Ketahanan pangan merupakan pilar utama sekaligus benteng terakhir ketahanan sebuah negara.

Beras merupakan salah satu komoditas strategis yang memiliki posisi sebagai makanan pokok masyarakat Indonesia yang masih tidak tergantikan, oleh karenanya pengembangan agribisnis beras di Indonesia ke depan tetap memiliki posisi strategis dilihat dari aspek ekonomi, sosial, maupun politik.

Peningkatan jumlah penduduk di Indonesia merupakan salah satu tantangan berat yang harus dihadapi oleh sektor pertanian khususnya tanaman pangan karena besarnya jumlah penduduk berkaitan langsung dengan penyediaan pangan. Peningkatan jumlah penduduk akan berpengaruh terhadap peningkatan jumlah permintaan pangan khususnya padi. Pada tahun 2015 jumlah penduduk Indonesia telah mencapai 252 juta jiwa, dengan laju pertumbuhan penduduk sebesar 1,4 persen (BPS, 2015).

Pemerintah perlu melakukan upaya peningkatan produksi padi secara terus-menerus untuk memenuhi kebutuhan pangan penduduk Indonesia serta untuk mencapai ketahanan pangan. Pada tahun 1984 Indonesia mampu mencapai swasembada beras melalui gerakan revolusi hijau, hal ini ditunjang oleh pengembangan varietas unggul baru (VUB), irigasi, dan penggunaan pupuk kimia (anorganik). Hingga saat ini, ketergantungan petani terhadap pupuk kimia sangat tinggi sehingga penggunaannya seringkali berlebihan. Hal ini terkait dengan respon tanaman terhadap penggunaan pupuk kimia sangat cepat dan didorong oleh adanya kebijakan subsidi pupuk. Hal tersebut menyebabkan turunnya kandungan bahan organik dalam tanah serta kemampuan tanah menyimpan dan melepaskan hara dan air bagi tanaman yang mengakibatkan produktivitas lahan menurun serta berdampak negatif terhadap kelestarian lingkungan (Balitbangtan, 2010). Dengan adanya dampak negatif dari penggunaan pupuk kimia yang berlebih, maka diperlukan upaya untuk mengembalikan kelestarian lingkungan, kesuburan dan produktivitas lahan salah satunya yaitu dengan mengembangkan pertanian ramah lingkungan yang berbasis bahan organik atau yang lebih dikenal dengan pertanian organik. Perkembangan pertanian ramah lingkungan menunjukkan kesadaran petani dan berbagai pihak yang berkontribusi dalam sektor pertanian akan pentingnya kesehatan dan keberlanjutan lingkungan.

Pertanian organik menurut IFOAM (International Federation of Organic Agriculture Movement) merupakan sistem manajemen produksi terpadu yang menghindari penggunaan pupuk buatan kimia, pestisida dan hasil rekayasa genetik, menekan pencemaran 
udara, tanah, dan air. Penggunaan masukan di luar pertanian yang menyebabkan kerusakan sumber daya alam tidak dapat dikategorikan sebagai pertanian organik, sebaliknya sistem pertanian yang tidak menggunakan masukan dari luar, namun mengikuti aturan pertanian organik dapat masuk dalam kelompok pertanian organik, meskipun agro-ekosistemnya tidak mendapat sertifikasi organik (IFOAM 2008).

Kesadaran masyarakat global
akan pentingnya menjaga keseimbangan kehidupan dengan lingkungan demi keberlangsungan hidup jangka panjang dan bahaya yang ditimbulkan oleh pemakaian bahan kimia sintetis dalam pertanian, mendorong produsen pangan untuk menghasilkan produk yang diinginkan oleh konsumen seperti aman dikonsumsi (food safety attributes), memiliki kandungan nutrisi tinggi (nutritional attributes) dan ramah lingkungan (eco-labelling attributes). Produk pangan yang memiliki ketiga atribut tersebut adalah produk yang dihasilkan dari sistem pertanian organik. Begitupun dengan masyarakat Indonesia yang mulai menyadari pentingnya kesehatan, salah satunya dengan mulai menerapkan pola hidup sehat dengan mengonsumsi bahan pangan organik. Sehingga gaya hidup masyarakat mulai bergeser yang mengakibatkan permintaan akan makanan organik mulai meningkat.

Tabel 1. Permintaan dan produksi

beras organik di Indonesia

\begin{tabular}{ccc}
\hline Tahun & $\begin{array}{c}\text { Produksi } \\
\text { (Ton) }\end{array}$ & $\begin{array}{c}\text { Permintaan } \\
\text { (Ton) }\end{array}$ \\
\hline 2005 & 550.300 & 550.300 \\
2006 & 557.179 & 660.360
\end{tabular}

\begin{tabular}{rrr}
2007 & 563.865 & 792.432 \\
2008 & 570.519 & 950.918 \\
2009 & 577.080 & 1.141 .102 \\
\hline
\end{tabular}

Sumber : Ahmad (2012)

Berdasarkan Tabel 1 dapat diketahui bahwa pada tahun 2005, Indonesia mampu memenuhi permintaan beras organik, sedangkan pada tahun-tahun selanjutnya besar permintaan selalu melebihi produksi di Indonesia yang artinya Indonesia mengalami defisit produksi padi organik untuk memenuhi kebutuhan. Sampai tahun 2009 permintaan padi organik mengalami kenaikan melebihi dua kali lipat dari tahun 2005. Dengan semakin terbukanya perdagangan bebas, sementara ketersediaan beras organik masih terbatas, maka pasar beras Indonesia dapat semakin dikuasai oleh beras organik impor.

Program pemerintah "Go Organic" merupakan salah satu pilihan program untuk mempercepat terwujudnya pembangunan agribisnis berwawasan lingkungan (ecoagribusiness) guna meningkatkan kesejahteraan masyarakat, khususnya petani. Misi program ini yaitu meningkatkan kualitas hidup masyarakat dan kelestarian lingkungan alam Indonesia, dengan mendorong berkembangnya pertanian organik yang berdaya saing dan berkelanjutan. Sedangkan tujuan yang ingin dicapai dari program ini adalah mewujudkan Indonesia sebagai salah satu produsen dan pengekspor pangan organik utama di dunia pada tahun 2010 (Deptan, 2005). Program tersebut mendukung para petani atau produsen produk pertanian membudidayakan komoditas pertanian secara organik dan mengusahakan hasil produknya. Dukungan tersebut diberikan melalui 
pelatihan-pelatihan serta fasilitas sarana dan prasarana budidaya pertanian secara organik. Melalui program tersebut, diharapkan produsen produk petanian lebih memilih membudidayakan komoditas pertanian dengan metode organik dibandingkan metode konvensional sehingga tanah menjadi subur dan lingkungan menjadi sehat kembali.

Kabupaten Cianjur merupakan salah satu Kabupaten di Jawa Barat yang menjadi sentra produksi beras dalam penyediaan stok pangan nasional khususnya di Jawa Barat. Kabupaten Cianjur sebagai salah satu sentra produksi padi yang memberikan kontribusi pangan beras sebesar 7,50\% untuk Jawa Barat dimana stok pangan nasional berasal dari Jawa Barat.

\section{KERANGKA PEMIKIRAN}

CV Pure Cianjur merupakan perusahaan yang fokus dalam usaha mengemas dan memasarkan beras dengan perlakuan organik dengan merk "Beras Cianjur Berasku" dan merupakan perintis dan satu-satunya perusahaan yang bisa menjual dan memasarkan beras tersebut ke perusahaan ritel yaitu Carrefour dan Transmart wilayah Bandung. Produk yang dipasarkan oleh CV Pure Cianjur antara lain adalah beras merah, beras pandanwangi, beras sintanur, beras hitam dan beras ciherang dengan kemasan $1 \mathrm{~kg}, 2 \mathrm{~kg}, 5 \mathrm{~kg}, 10 \mathrm{~kg}, 2.5 \mathrm{~kg}$ dengan volume penjualannya sebesar $7.900 \mathrm{~kg}$ per bulan. Beras yang dipasarkan oleh CV Pure Cianjur adalah beras sehat, artinya beras tersebut dibudidayakan dengan perlakuan organik dan ramah lingkungan, namun belum memiliki sertifikat organik dari lembaga sertifikasi organik yang sudah diakui.

Dalam melakukan usahanya, CV

Pure Cianjur bermitra dengan Kelompok Tani Bangkit, Desa Babakan Karet, Kecamatan Cianjur sebagai pemasok beras, yang memiliki anggota 21 orang dan luas lahannya sekitar 20 hektar. Selain melakukan kerjasama, CV Pure Cianjur juga melakukan pembinaan kepada Kelompok Tani Bangkit terutama di bidang budidaya pertanian dengan perlakuan organik.

Berdasarkan hasil wawancara pra survey dengan Pemilik CV, pada bulan November 2016 CV Pure Cianjur tidak mampu memenuhi permintaan beras sehat dari Carrefour dikarenakan banyak anggota Kelompok Tani Bangkit sebagai pemasok mengalami gagal panen diakibatkan oleh curah hujan yang sangat tinggi. Dengan demikian, hal ini mengganggu kekontinuitasan CV Pure Cianjur dalam memenuhi permintaan distributor.

Permasalahan lain yang dihadapi oleh CV Pure Cianjur dalam menjalankan usahanya adalah kesulitan mendapatkan pasokan beras sehat selain dari Kelompok Tani Bangkit sebagai pemasok, dikarenakan beras sehat yang dijual oleh perusahaan adalah beras yang murni tanpa campuran, beras kepala serta perlakuannya organik sehingga membuat perusahaan kesulitan mendapatkan pasokan yang kontinu sesuai dengan persyaratan tersebut. Pasokan beras dengan perlakuan organik selain dari Kelompok Tani Bangkit sulit didapat juga dikarenakan masih belum banyak petani yang melakukan budidaya organik. 
Berdasarkan data yang didapat dari GPO Cianjur (2012), sampai dengan tahun 2012 sebanyak 430 petani Kabupaten Cianjur telah mengikuti pelatihan dan diharapkan dapat menyebarkan sistem pertanian padi organik ke petani lainnya, namun faktanya petani yang menerapkan pertanian padi organik hanya sebanyak 156 orang yaitu sekitar 36,28 persen dari petani peserta pelatihan atau 0,05 persen dari total petani padi sebanyak 296.549 orang dengan luas lahan hanya sebesar 79.3 ha atau sekitar 0,13 persen dari luasan lahan sawah seluas 63.299 ha.

Ketika mengalami kekurangan pasokan untuk memenuhi permintaan, manajemen CV Pure Cianjur pernah beberapa kali mengambil pasokan dari petani di luar kelompok yang melakukan budidaya padi dengan perlakuan organik, namun malah mengalami kerugian, karena pasokan yang didapat tidak sesuai dengan standar produk yang ditetapkan oleh CV Pure Cianjur, yaitu harus beras kepala dan murni tanpa campuran.

Potensi CV Pure Cianjur sebagai perintis dan satu-satunya perusahaan di Kabupaten Cianjur yang menjual beras sehat perlakuan organik ke perusahaan ritel Carrefour dan Transmart masih sangat besar. Mengingat seiring dengan peningkatan pendapatan dan peningkatan pendidikan, juga peningkatan kesadaran terhadap kesehatan saat ini, maka minat terhadap beras sehat (beras dengan perlakuan organik) semakin besar.

Berdasarkan uraian tersebut
maka CV Pure Cianjur harus
melakukan strategi pengembangan
usaha dengan memilih dan
mengalokasikan sumberdaya yang

terbatas tersebut secara efektif dan efisien agar dapat menstabilkan usaha. Hal ini dilakukan guna memenuhi dan mempertahankan posisi usaha serta permintaan yang ada ditengah persaingan yang terus berkembang. Strategi pengembangan digunakan agar peluang, potensi dan sumber daya yang dimiliki CV Pure Cianjur dapat termanfaatkan dengan baik dan kendala serta ancaman yang dihadapi mampu teratasi. Strategi pengembangan juga diperlukan agar CV Pure Cianjur mampu mengantisipasi berbagai perubahan yang terjadi.

\section{METODE PENELITIAN}

\section{Lokasi dan Waktu Penelitian}

Data yang digunakan dalam penelitian ini adalah data primer dan sekunder. Data primer diperoleh melalui pengamatan langsung atau observasi, wawancara mendalam dengan beberapa responden ahli dan pengisian kuesioner dengan dipandu oleh peneliti. Beberapa responden terkait adalah responden internal yaitu pemilik perusahaan yang juga merupakan pimpinan perusahaan, manajer bagian pemasaran dan agribisnis serta manajer keuangan. Sedangkan yang merupakan responden eksternal adalah petani di Kelompok Tani Bangkit sebagai pemasok, pembeli dalam hal ini Manajer Carrefour dan Transmart di wilayah Bandung, dan Pihak Dinas Pertanian Tanaman Pangan dan Hortikultura Kabupaten Cianjur. Data primer yang diperoleh meliputi gambaran umum, visi, misi, tujuan, sasaran, serta informasi mengenai lingkungan internal dan eksternal dari CV Pure 
Cianjur. Data sekunder diperoleh melalui study literature dari penelitian terdahulu, buku, jurnal, internet, dan literatur lain yang berhubungan dengan topik penelitian. Selain itu data penunjang diperoleh dari instansi terkait seperti Dinas Pertanian Tanaman Pangan dan Hortikultura Kabupaten Cianjur dan BPPK Kecamatan Cianjur.

\section{Analisis Alternatif Strategi Pengembangan dengan A'WOT}

Data yang didapatkan akan diolah dan dianalisis secara kuantitatif diskriptif. Analisis diskriptif digunakan untuk menjelaskan kondisi secara faktual yang didapatkan di lapangan tentang profil CV Pure Cianjur, mengidentifikasi dan menganalisis faktor-faktor penentu pengembangan usaha beras sehat CV Pure Cianjur. Analisis kuantitatif digunakan dalam penilaian terhadap perumusan strategi usaha beras sehat CV Pure Cianjur. Perumusan strategi mengunakan metode A'WOT yang merupakan kombinasi dari AHP (Analytical Hierarchy Process) dengan analisis SWOT (Stengths, Weaknesses, Opportunities dan Threats). Analisis SWOT digunakan untuk memaksimalkan peluang dan kekuatan serta meminimalkan kelemahan dan ancaman (Pearce \& Robinson, 2008).

Analisis SWOT merupakan alat analisis kualitatif yang digunakan untuk menghasilkan alternatif startegi SO, ST, WO, WT dengan mempertimbangkan faktor eksternal maupun internal perusahaan (David 2009). Metode AHP digunakan dalam pemberian bobot atau kepentingan dari tiap tingkatnya dan memberikan penilaian untuk mengetahui strategi tepat dari alternatif-alternatif strategi yang dihasilkan dalam matriks SWOT (Kurtilla et al, 2001 ; Gorener et al, 2012). Selanjutnya, nilai skor yang diperoleh dari penyebaran kuisioner ke para ahli kemudian dianalisis dan diproses dengan menggunakan aplikasi software Expert Choice, 2000. Faktorfaktor eksternal dan internal dari elemen-elemen kunci pengembangan usaha beras sehat CV Pure Cianjur dianalisis yang kemudian faktor-faktor yang telah ada tersebut di identifikasi menjadi kekuatan, kelemahan, peluang dan ancaman perusahaan dengan menggunakan SWOT analisis. Setelah itu dilakukan formulasi strategi faktorfaktor dengan menggunakan perbandingan masing-masing faktor yang menjadi kekuatan (strength), kelemahan (weakness), peluang (opportunity) dan ancaman (threats) dengan menggunakan metode AHP. Dengan demikian untuk melengkapi SWOT tersebut dapat dikombinasikan AHP dengan melakukan perbandingan untuk mendapatkan strategi utama berdasarkan kepentingannya (Kurtilla et al, 2001). Penggunaan metode Analytical Hierarchy Process (AHP) juga digunakan dalam memilih strategi yang diprioritaskan dalam pengembangan usaha beras sehat $\mathrm{CV}$ Pure Cianjur.

Hierarki dalam penelitian terstruktur terdapat 4 tingkatan yakni tingkat pertama, tujuan yang ingin dicapai oleh keputusan tingkat berikutnya didasari oleh empat kelompok faktor seperti yang didefinisikan oleh teknik SWOT yaitu Strengths (S), Weakness (W), Opportunity (O) dan Threats (T), tingkat ketiga didasari oleh subfaktorsubfaktor yang termasuk dalam 
masing-masing dari empat kelompok tingkat sebelumnya, dan tingkat keempat didasari oleh strategi yang harus dievaluasi dan dibandingkan. (Kurtilla et al. 2001; Osuno \& Aranda 2007; Gorener et al. 2012 ; Oreski 2012). Setelah itu, strategi yang sudah didapatkan akan dijabarkan kedalam program-program yang disusun dengan menggunakan Arsitektur Strategi.

Metode AHP (Analytical Hierarchy Process) diperlukan untuk memperoleh pendapat para pakar yang memahami objek penelitian sehingga diperoleh suatu arahan yang tepat berdasarkan pertimbangannya. Adapun analisis SWOT adalah alat untuk mendukung keputusan strategis berdasarkan empat komponen. yaitu kekuatan (Strength), kelemahan (Weakness), peluang (Opportunity), dan ancaman (Threat). Tujuan menerapkan AHP dan SWOT (A'WOT) adalah untuk mengembangkan dan mengadopsi strategi yang cocok di antara keempat faktor tersebut, dimana SWOT memberikan kerangka dasar untuk melakukan analisis situasi keputusan dan AHP membantu dalam menerapkan SWOT secara lebih analitis (Kangas et al. 2001).

Langkah-langkah menggunakan metode A'WOT adalah sebagai berikut (Kurttila et al, 2000) :

1. Melakukan analisis SWOT, pada langkah ini mengidentifikasi terlebih dahulu faktor internal dan faktor eksternal yang mempengaruhi pengembangan perusahaan dan dimasukkan dalam analisis SWOT. Ketika menerapkan metode standar dari AHP, dianjurkan bahwa jumlah faktor dalam kelompok SWOT tidak melebihi 10 karena jumlah perbandingan berpasangan yang dibutuhkan dalam analisis ini berkembang.

2. Melakukan perbandingan berpasangan antara faktor SWOT dalam setiap kelompok SWOT. Ketika membuat perbandingan, pertanyaan-pertanyaan yang diajukan adalah 1) yang mana dari dua faktor yang dibandingkan yang lebih besar kekuatannya (peluang, kelemahan, atau ancaman) dan 2) seberapa besar kekuatannya. Dengan perbandingan ini sebagai masukan, prioritas lokal relatif dari faktor dihitung dengan menggunakan metode nilai eigen. Prioritas ini mencerminkan persepsi pembuat keputusan dari kepentingan relatif dari faktorfaktor. Perbandingan berpasangan dilakukan dengan menyusun matriks, dilakukan perbandingan berpasangan antar setiap elemen pada kolom ke-i dengan setiap elemen baris ke-j. Untuk mengisi matriks berpasangan, digunakan skala banding berpasangan. Angka tersebut menunjukkan relatif pentingnya suatu elemen dibandingkan dengan elemen lainnya sehubungan dengan sifat atau kriteria tertentu. Pengisian matriks harus dilakukan untuk bagian di atas garis diagonal dan di bawah garis diagonal.

Perbandingan berpasangan dilakukan untuk melihat pengaruh setiap elemen yang relevan atas setiap kriteria yang berpengaruh yang berasal setingkat di atasnya. Perbandingan berpasangan dilakukan dengan 
menghubungkan semua elemen setiap levelnya. Kemudian dilakukan pembobotan terhadap kriteria dengan perbandingan berpasangan dengan skala 1 sampai dengan 9 .

Tabel 2. Matriks perbandingan berpasangan antar subfaktor

\begin{tabular}{ccccc}
\hline $\mathbf{C}$ & $\mathbf{A 1}$ & $\mathbf{A 2}$ & $\ldots$ & $\mathbf{A n}$ \\
\hline $\mathrm{A} 1$ & 1 & $\ldots$ & $\ldots$ & $\ldots$ \\
$\mathrm{A} 2$ & $\ldots$ & 1 & $\ldots$ & $\ldots$ \\
$\ldots$ & $\ldots$ & $\ldots$ & 1 & $\ldots$ \\
$\mathrm{An}$ & $\ldots$ & $\ldots$ & $\ldots$ & 1 \\
\hline
\end{tabular}

Pengalaman telah membuktikan bahwa skala dengan sembilan satuan dapat diterima dan mencerminkan derajat sampai mana seseorang mampu membedakan intensitas tata hubungan antar elemen

3. Perbandingan berpasangan yang dibuat antara empat kelompok SWOT

Faktor dengan prioritas lokal tertinggi dipilih dari masing- masing kelompok untuk mewakili kelompok. Keempat faktor ini kemudian dibandingkan dan prioritas relatifnya dihitung seperti pada Langkah 2. Ini adalah faktor skala dari empat kelompok SWOT dan digunakan untuk menghitung prioritas global dari faktor independen dalam setiap kelompok. Hal ini dilakukan dengan mengalikan prioritas lokal faktor dengan nilai faktor skala yang sesuai dari kelompok SWOT. Jumlah prioritas global jika dijumlahkan bernilai satu.

4. Menggunakan hasil dalam perumusan strategi dan proses evaluasi. Kontribusi terhadap proses perencanaan strategis datang dalam bentuk nilai-nilai numerik untuk faktor. Target baru dapat diatur, strategi didefinisikan dan rencana pelaksanaan mempertimbangkan berdasarkan faktor yang paling penting. Pada tahap ini perumusan strategi

Tabel 3. Skala banding secara berpasangan

\begin{tabular}{|c|c|c|}
\hline $\begin{array}{c}\text { Intensitas } \\
\text { Kepentingan }\end{array}$ & Definisi & Penjelasan \\
\hline 1 & Kedua elemen sama pentingnya & $\begin{array}{l}\text { Dua elemen menyumbangnya sama } \\
\text { besar pada sifat itu }\end{array}$ \\
\hline 3 & $\begin{array}{l}\text { Elemen yang satu sedikit lebih } \\
\text { penting daripada yang lainnya }\end{array}$ & $\begin{array}{l}\text { Pengalaman dan pertimbangan sedikit } \\
\text { menyokong satu elemen atas lainnya }\end{array}$ \\
\hline 5 & $\begin{array}{l}\text { Elemen yang satu sangat } \\
\text { penting daripada elemen lainnya }\end{array}$ & $\begin{array}{l}\text { Pengalaman dan pertimbangan dengan } \\
\text { kuat menyokong satu elemen atas } \\
\text { lainnya }\end{array}$ \\
\hline 7 & $\begin{array}{l}\text { Satu elemen jelas lebih penting } \\
\text { daripada lainnya }\end{array}$ & $\begin{array}{l}\text { Satu elemen yang kuat disokong dan } \\
\text { dominannya terlihat dalam praktik }\end{array}$ \\
\hline 9 & $\begin{array}{l}\text { Satu elemen mutlak lebih } \\
\text { penting daripada lainnya }\end{array}$ & $\begin{array}{l}\text { Bukti yang menyokong elemen yang } \\
\text { satu atas yang lainnya memiliki tingkat } \\
\text { yang mungkin menguatkan }\end{array}$ \\
\hline Intensitas & Definisi & Penjelasan \\
\hline \multicolumn{3}{|l|}{ Kepentingan } \\
\hline $2,4,6,8$ & $\begin{array}{l}\text { Nilai-nilai diantara dua } \\
\text { pertimbangan yang berdekatan }\end{array}$ & $\begin{array}{l}\text { Kompromi diperlukan diantara dua } \\
\text { pertimbangan }\end{array}$ \\
\hline
\end{tabular}
pertimbangan 


\begin{tabular}{|c|c|c|}
\hline Faktor Eksternal & Strenghts (S) & Weakness (W) \\
\hline Opportunities (O) & $\begin{array}{l}\text { Strategi S-O } \\
\text { strategi disini yaitu } \\
\text { menggunakan kekuatan } \\
\text { untuk memanfaatkan } \\
\text { peluang }\end{array}$ & $\begin{array}{l}\text { Staregi W-O } \\
\text { strategi di sini yaitu } \\
\text { memanfaatkan peluang untuk } \\
\text { mengatasi kelemahan }\end{array}$ \\
\hline Threats $(\mathrm{T})$ & \begin{tabular}{lr}
\multicolumn{2}{l}{ Strategi S-T } \\
strategi di & sini yaitu \\
menggunakan & kekuatan \\
untuk & menghindari \\
ancaman &
\end{tabular} & $\begin{array}{l}\text { Strategi W-T } \\
\text { strategi di sini yaitu } \\
\text { meminimalkan kelemahan dan } \\
\text { menghindari ancaman }\end{array}$ \\
\hline
\end{tabular}

Gambar 1. Matriks SWOT

Sumber : Wheelen dan Hunger (2008)

dilakukan dengan mencocokkan antara faktor internal dan eksternal. Faktor internal dan eksternal merupakan data yang telah diperoleh dari tahap input. Pada tahap ini alat analisis yang digunakan adalah matriks SWOT yang dapat dilihat pada Gambar 1.

\section{Arsitektur strategi}

Menurut Yoshida (2006), arsitektur strategi merupakan pendekatan yang lebih fleksibel dalam melakukan perencanaan strategi sekaligus sebagai solusi untuk menghadapi perubahan lingkungan bisnis yang sangat dinamis. Arsitektur strategi disusun dengan memperhatikan beberapa unsur yaitu visi dan misi organisasi, analisis lingkungan internal dan eksternal, industry foresight, sasaran dan tantangan organisasi. Kerangka perencanaan arsitektur strategi pada CV Pure Cianjur dapat dilihat pada gambar 2 .

Adapun proses pembuatan arsitektur strategis menurut Yoshida (2006) adalah sebagai berikut :

1. Mendeskripsikan sasaran jangka panjang dan tantangan CV Pure Cianjur melalui melalui wawancara mendalam dengan pakar.

2. Melakukan analisis internal dan eksternal (makro dan mikro) untuk mengetahui faktor-faktor strategis

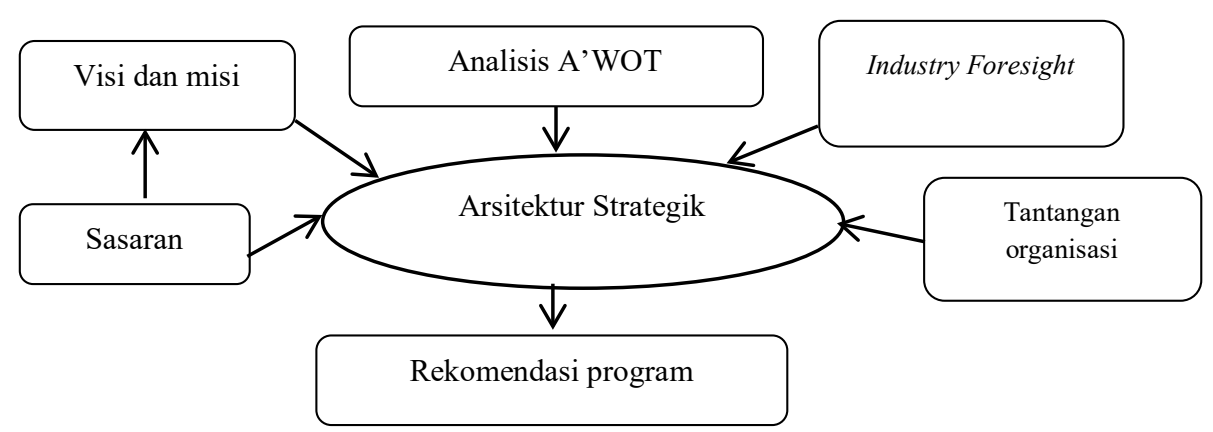

Gambar 2. Kerangka perencanaan arsitektur strategi pada CV Pure Cianjur 


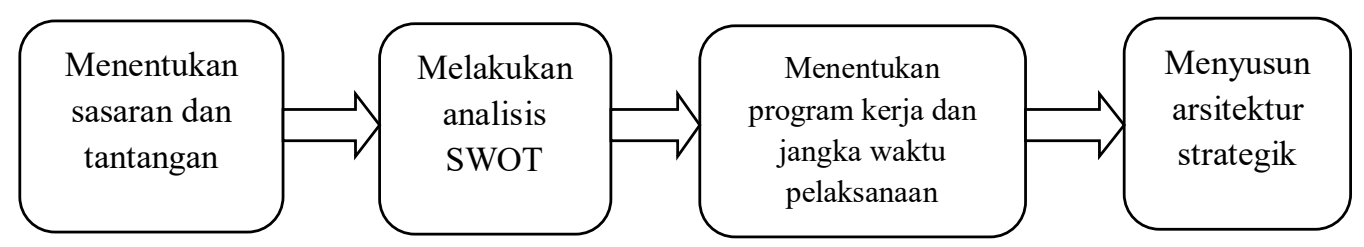

\section{Gambar 3. Tahapan pembuatan arsitektur strategis}

dari industri yang dimasuki oleh $\mathrm{CV}$ Pure Cianjur.

3. Melakukan perumusan alternatif strategi dan penilaian prioritas terhadap setiap level hirarki melalui matriks perbandingan/komparasi berpasangan.

4. Membuat program kerja yang diturunkan dari alternatif strategi dengan mempertimbangkan kemampuan, waktu dan sumberdaya perusahaan

5. Menentukan jangka waktu pelaksanaan program kerja atau disebut industry foresight dengan mengidentifikasi kesenjangan antara kondisi saat ini dan kondisi yang diharapkan sebagai dasar perkiraan kebutuhan waktu pencapaian tujuan

6. Menyusun arsitektur strategik CV Pure Cianjur berdasarkan industry foresight dan sasaran yang telah dibuat dan dirancang dapat di lihat pada Gambar 3.

\section{HASIL DAN PEMBAHASAN}

Pada Tabel 4 merupakan hasil penilaian AHP dari faktor-faktor SWOT yang dilakukan oleh para pakar. Para pakar menilai bahwa faktor yang paling penting adalah faktor peluang $(0,415)$. Selanjutnya faktor kedua yang dianggap penting adalah faktor kekuatan $(0,360)$, faktor kelemahan $(0,126)$ serta faktor ancaman $(0,099)$.

Faktor kekuatan dapat memberikan kondisi yang menguntungkan apabila CV Pure
Cianjur dapat mempertahankan dan mengoptimalkannya. Pada faktor kekuatan, produk yang dimiliki perusahaan berkualitas $(0,377)$ menjadi penilaian yang dianggap para pakar penting untuk dipertimbangankan dan dikembangkan. Hal ini dikarenakan beras organic dengan merek beras cianjur berasku CV Pure Cianjur tidak diragukan lagi kualitasnya dan sudah dikenal baik oleh para konsumennya, terlebih memang beras cianjur sudah dikenal kualitasnya oleh masyarakat umum yang pulen dan lezat. Hal ini sesuai dengan penelitian yang dilakukan oleh Agustina (2011) dengan hasil bahwa kualitas produk merupakan faktor utama yang mempengaruhi masyarakat dalam pembelian beras organik.

Pada faktor kelemahan, penilaian yang dianggap penting para pakar untuk bisa diminimalkan adalah sub faktor diskontinuitas bahan baku $(0,402)$ karena beberapa kali ketika pesanan dan permintaan dari Careffour sedang tinggi, perusahaan tidak mampu memenuhi permintaan tersebut. Hal ini diakibatkan pasokan bahan baku dari kelompok tani mitra perusahaan yaitu kelompok tani Bangkit tidak mampu memenuhi permintaan yang ada. Hasilnya perusahaan membeli pasokan dari kelompok tani ataupun dari petani lain yang mengusahakan beras dengan perlakuan organik, tapi kualitas beras yang dihasilkan tidak sebagus beras yang dihasilkan oleh kelompok tani 
Tabel 4. Bobot Prioritas faktor SWOT Pengembangan Usaha Beras Sehat CV Pure Cianjur

\begin{tabular}{|c|c|c|c|}
\hline & Inconsistency & Lokal & Global \\
\hline \multicolumn{4}{|l|}{ Faktor Internal } \\
\hline Kekuatan & 0,04 & & 0,360 \\
\hline 1. Produk berkualitas & & 0,377 & 0,136 \\
\hline $\begin{array}{l}\text { 2. Harga produk bersaing dengan } \\
\text { kompetitor }\end{array}$ & & 0,134 & 0,048 \\
\hline 3. Memiliki legalitas kesehatan (PIRT) & & 0,302 & 0,109 \\
\hline 4. Segmentasi pasar pasti dan jelas & & 0,188 & 0,068 \\
\hline Kelemahan & 0,07 & & 0,126 \\
\hline $\begin{array}{l}\text { 1. Kemasan, logo, dan brand kurang } \\
\text { menarik }\end{array}$ & & 0,104 & 0,013 \\
\hline 2. Belum memiliki sertifikasi organik & & 0,050 & 0,006 \\
\hline 3. Diskontinuitas pasokan bahan baku & & 0,402 & 0,051 \\
\hline $\begin{array}{l}\text { 4. Pengorganisasian manajemen belum } \\
\text { berjalan baik dan profesional }\end{array}$ & & 0,205 & 0,026 \\
\hline $\begin{array}{l}\text { 5. Promosi dan ekspansi pasar belum } \\
\text { maksimal }\end{array}$ & & 0,159 & 0,020 \\
\hline 6. Teknologi yang dimiliki masih terbatas & & 0,080 & 0,010 \\
\hline \multicolumn{4}{|l|}{ Faktor Eksternal } \\
\hline Peluang & 0,07 & & 0,415 \\
\hline $\begin{array}{l}\text { 1. Sumberdaya alam yang dimiliki } \\
\text { Kabupaten Cianjur }\end{array}$ & & 0,181 & 0,075 \\
\hline 2. Gaya hidup sehat masyarakat & & 0,090 & 0,037 \\
\hline 3. Tingkat pendidikan masyarakat & & 0,169 & 0,070 \\
\hline 4. Tingkat pendapatan masyarakat & & 0,132 & 0,055 \\
\hline 5. Perkembangan teknologi informasi & & 0,059 & 0,024 \\
\hline $\begin{array}{l}\text { 6. Dukungan pemerintah pusat dan } \\
\text { provinsi }\end{array}$ & & 0,062 & 0,026 \\
\hline $\begin{array}{l}\text { 7. Peluang pasar dan permintaan beras } \\
\text { organik masih besar }\end{array}$ & & 0,172 & 0,071 \\
\hline $\begin{array}{l}\text { 8. Potensi pertanian organik masih } \\
\text { berkembang }\end{array}$ & & 0,136 & 0,057 \\
\hline Ancaman & 0,07 & & 0,099 \\
\hline 1. Kompetitor dengan produk sejenis & & 0,089 & 0,009 \\
\hline 2. Daya beli konsumen rendah & & 0,232 & 0,023 \\
\hline $\begin{array}{l}\text { 3. Edukasi dan informasi mengenai } \\
\text { kelebihan beras organik }\end{array}$ & & 0,178 & 0,018 \\
\hline $\begin{array}{l}\text { 4. Persaingan dalam industri semakin } \\
\text { tinggi }\end{array}$ & & 0,151 & 0,015 \\
\hline 5. Produk substitusi (beras anorganik) & & 0,349 & 0,034 \\
\hline Total Penilaian Global & & & 1,000 \\
\hline
\end{tabular}

Sumber : Data primer diolah (2017)

Bangkit, hal ini tidak sesuai dengan standar yang ditetapkan perusahaan ketika akan menerima pasokan bahan baku, sehingga saat itu CV Pure Cianjur mengalami kerugian. 
Faktor peluang memberikan kondisi yang menguntungkan apabila perusahaan dapat memanfaatkannya. Faktor peluang terdiri beberapa kondisi dimana potensi pertanian organik masih berkembang, peluang pasar dan permintaan beras organik masih besar, sumber daya manusia (SDA) yang dimiliki Kabupaten Cianjur, gaya hidup sehat masyarakat, tingkat pendidikan masyarakat, tingkat pendapatan masyarakat, perkembangan teknologi informasi dan dukungan pemerintah pusat maupun provinsi. Faktor yang dianggap penting oleh pakar untuk dimanfaatkan adalah SDA yang dimiliki oleh Kabupaten Cianjur $(0,181)$ yang dapat mendukung perkembangan pertanian organik khususnya beras sehingga mendukung pengoperasian perusahaan.

Faktor eksternal menjadi pertimbangan yang terakhir adalah faktor ancaman. Dimana para pakar menilai bahwa pada faktor ancaman yang paling utama adalah produk substitusi yaitu beras anorganik atau konvensional $(0,349)$. Produsen beras anorganik menjadi ancaman berat bagi CV Pure Cianjur. Dibandingkan beras konvensional, beras organik relatif lebih mahal harganya mengingat banyaknya manfaat yang didapatkan konsumen (Lohr, 2001). Namun demikian promosi dan informasi pasar untuk beras anorganik lebih besar dan lebih baik sehingga masyarakat lebih gencar membeli produk anorganik. Selain dari pada itu produsen beras anorganik juga sering memberikan promosi berupa diskon yang membuat harga beras anorganik semakin terjangkau masyarakat dan bisa menggeser permintaan beras organik.
Alternatif strategi yang akan direkomendasikan kepada CV Pure Cianjur dirumuskan dengan matriks SWOT dari hasil analisis semua faktorfaktor eksternal dan internal. Faktorfaktor tersebut meliputi kekuatan, kelemahan, peluang dan ancaman. Analisis SWOT merupakan perumusan strategi yang mendasari bentuk strategi yang disesuaikan dengan kondisi lingkungan perusahaan baik internal maupun eksternal dan pasar. Beberapa alternatif strategi yang telah dirumuskan dapat dilihat pada analisis matriks SWOT CV Pure Cianjur pada Gambar 4. Berdasarkan penilaian pembobotan AHP pada Tabel 5, dapat dilihat bahwa prioritas strategi menurut pakar yang pertama adalah melakukan persiapan dan pendaftaran untuk mendapatkan sertifikasi organik. Pada prioritas kedua yaitu melakukan pembinaan dan perluasan areal lahan dengan kelompok tani mitra (Kelompok Tani Bangkit). Prioritas yang ketiga adalah melakukan perbaikan kemasan, logo, dan merk produk untuk meningkatkan dayasaing produk. Prioritas yang keempat adalah meningkatkan asset investasi berupa alat sortir beras,. Prioritas kelima adalah mempertahankan kualitas produk dan mengembangkan produk turunan beras organik dengan optimalisasi sumberdaya yang ada pada perusahaan untuk memenangkan persaingan. Prioritas keenam adalah memberikan edukasi kepada masyarakat mengenai kelebihan dan manfaat beras organik. Prioritas ketujuh adalah meningkatkan produksi dengan pendekatan backward integration yaitu dengan membina kelompok tani ataupun petani lain yang berpotensi untuk menjadi mitra dalam 


\begin{tabular}{|c|c|c|}
\hline Faktor Eksternal & $\begin{array}{l}\text { Kekuatan (Strenght) } \\
\text { 1. Produk berkualitas } \\
\text { 2. } \begin{array}{l}\text { Harga produk bersaing dengan } \\
\text { kompetitor }\end{array} \\
\text { 3. } \begin{array}{l}\text { Memiliki legalitas kesehatan } \\
\text { (PIRT) }\end{array} \\
\text { 4. } \begin{array}{l}\text { Segmentasi pasar pasti dan } \\
\text { jelas }\end{array}\end{array}$ & $\begin{array}{l}\text { Kelemahan (Weakness) } \\
\text { 1. Kemasan, logo, dan merek } \\
\text { produk kurang menarik } \\
\text { 2. } \begin{array}{l}\text { Belum memiliki sertifikasi } \\
\text { organik }\end{array} \\
\text { 3. } \begin{array}{l}\text { Diskontinuitas pasokan bahan } \\
\text { baku }\end{array} \\
\text { 4. } \begin{array}{l}\text { Pengorganisasian manajemen } \\
\text { belum berjalan baik dan } \\
\text { profesional }\end{array} \\
\text { 5. } \begin{array}{l}\text { Promosi dan ekspansi pasar } \\
\text { belum maksimal }\end{array} \\
\text { Teknologi yang dimiliki } \\
\text { perusahaan masih terbatas }\end{array}$ \\
\hline Peluang (Opportunity) & Strategi S-O & Strategi W-O \\
\hline $\begin{array}{l}\text { 1. Sumber daya alam yang dimiliki } \\
\text { Kabupaten Cianjur } \\
\text { 2. Gaya hidup sehat masyarakat } \\
\text { 3. Tingkat pendidikan masyarakat } \\
\text { 4. Tingkat pendapatan masyarakat } \\
\text { 5. Perkembangan teknologi informasi } \\
\text { 6. Dukungan pemerintah pusat maupun } \\
\text { provinsi } \\
\text { 7. Peluang pasar dan permintaan beras } \\
\text { organik masih besar } \\
\text { 8. Potensi pertanian organik semakin } \\
\text { berkembang }\end{array}$ & $\begin{array}{l}\text { 1. Melakukan perluasan jaringan } \\
\text { pasar }(\mathrm{S} 1, \mathrm{~S} 2, \mathrm{~S} 3, \mathrm{~S} 4, \mathrm{O} 1, \mathrm{O} 2, \mathrm{O} 7, \\
\mathrm{O} 8) \\
\text { 2. Meningkatkan produksi dengan } \\
\text { pendekatan backward integration } \\
\text { yaitu dengan membina kelompok } \\
\text { tani ataupun petani lain yang } \\
\text { berpotensi untuk menjadi mitra } \\
\text { dalam rangka menjamin pasokan } \\
\text { bahan baku } \\
(\mathrm{S} 1, \mathrm{~S} 2, \mathrm{~S} 3, \mathrm{~S} 4, \mathrm{O} 1, \mathrm{O} 2, \mathrm{O} 6, \mathrm{O} 7, \mathrm{O} 8)\end{array}$ & $\begin{array}{l}\text { 1. Melakukan pembinaan dan } \\
\text { perluasan areal lahan dengan } \\
\text { kelompok tani mitra (Kelompok } \\
\text { tani Bangkit) (W3,O1,O7,O8) } \\
\text { 2. Meningkatkan aset investasi berupa } \\
\text { alat sortir beras (W6,O7) }\end{array}$ \\
\hline $\begin{array}{l}\text { Ancaman (Threath) } \\
\text { 1. Kompetitor dengan produk sejenis } \\
\text { 2. Daya beli konsumen rendah } \\
\text { 3. Edukasi dan informasi mengenai } \\
\text { kelebihan beras organik } \\
\text { 4. Persaingan dalam industri tinggi } \\
\text { 5. Produk substitusi (beras anorganik) }\end{array}$ & $\begin{array}{l}\text { Strategi S-T } \\
\text { 1. Mempertahankan kualitas produk } \\
\text { dan mengembangkan produk } \\
\text { turunan beras organik dengan } \\
\text { optimalisasi sumberdaya yang } \\
\text { ada pada perusahaan untuk } \\
\text { memenangkan persaingan } \\
(\mathrm{S} 1, \mathrm{~S} 2, \mathrm{~S} 3, \mathrm{~T} 1, \mathrm{~T} 4) \\
\text { 2. Memberikan edukasi kepada } \\
\text { masyarakat mengenai kelebihan } \\
\text { dan manfaat beras organik } \\
(\mathrm{S} 1, \mathrm{~S} 4, \mathrm{~T} 3)\end{array}$ & $\begin{array}{l}\quad \text { Strategi W-T } \\
\text { Melakukan perbaikan kemasan, } \\
\text { logo, dan merek produk untuk } \\
\text { meningkatkan dayasaing produk } \\
\text { (W1, T1,T4) } \\
\text { Melakukan persiapan dan } \\
\text { pendaftaran untuk mendapatkan } \\
\text { sertifikasi organik (W2, T1, T4, } \\
\text { T5) }\end{array}$ \\
\hline
\end{tabular}

\section{Gambar 4. Analisis Matriks SWOT CV Pure Cianjur}

rangka menjamin pasokan bahan baku. Prioritas kedelapan yaitu melakukan perluasan jaringan pasar.

Prioritas strategi yang paling utama adalah melakukan persiapan dan pendaftaran untuk mendapatkan sertifikasi organik. Strategi ini sangat baik untuk dilakukan dalam rangka mengembangkan usaha beras sehat $\mathrm{CV}$ Pure Cianjur. Konsumen akan lebih yakin dan tertarik untuk membeli beras organik ketika sudah memiliki sertifikasi organik dari lembaga sertifikasi pangan organik yang telah diakui.

Penelitian yang dilakukan oleh Lohr (1998) juga sepemikiran, bahwa fungsi dari sertifikasi organik bagi konsumen adalah memastikan konsumen mendapatkan produk yang diperlakukan berbeda dengan produk nonorganik yang sesuai dengan aturan ramah lingkungan, dan bagi produsen untuk tidak menipu dan menggunakan 
Tabel 5. Penilaian dalam Penentuan Urutan Prioritas Strategi Pengembangan

Incon-
sistency Hasil Pembobotan Strategi
Bobot

0,047

0,056

kelompok tani ataupun petani lain yang berpotensi untuk menjadi mitra dalam rangka menjamin pasokan bahan baku (S1, S2, S3, S4, O1, O2, O6, O7, O8)

3. Melakukan pembinaan dan perluasan areal lahan dengan kelompok tani mitra (Kelompok tani Bangkit) (W3,O1,O7,O8)

4. Meningkatkan aset investasi berupa alat sortir beras (W6, O7)

5. Mempertahankan kualitas produk dan mengembangkan produk turunan beras organik dengan optimalisasi sumberdaya yang ada pada perusahaan untuk memenangkan persaingan (S1,S2,S3,T1,T4)

6. Memberikan edukasi kepada masyarakat mengenai kelebihan dan manfaat beras organik $(\mathrm{S} 1, \mathrm{~S} 4, \mathrm{~T} 3)$

7. Melakukan perbaikan kemasan, logo, dan merek produk untuk meningkatkan dayasaing produk (W1, $\mathrm{T} 1, \mathrm{~T} 4)$

8. Melakukan persiapan dan pendaftaran untuk mendapatkan sertifikasi organik (W2, T1, T4, T5)

$\begin{array}{ll}0,047 & 8 \\ 0,056 & 7 \\ 0,181 & 2 \\ 0,09 & 4 \\ 0,111 & \\ 0,081 & 5 \\ 0,063 & 6 \\ 0,163 & 3 \\ 0,299 & 1\end{array}$

Sumber : Data primer diolah (2017)

secara tidak baik dari kata organik hanya untuk mendapatkan harga premium. Dengan adanya sertifikasi tersebut dinilai lebih memberikan rasa kepercayaan dan keamanan bagi konsumen yang mengkonsumsi bahan pangan organik, bahwa produk tersebut diusahakan dan dibudidayakan dengan perlakuan organik tanpa menggunakan bahan kimia baik pestisida maupun pupuknya.

Hierarki pada model AHP merupakan bagian yang penting karena digunakan sebagai dasar bagi responden untuk memberikan pembobotan secara lebih sederhana.
Diharapkan dengan hierarki ini permasalahan yang kompleks dapat terlihat lebih sederhana dan mudah dipahami. Metode A'WOT ini merupakan penggunaan AHP dengan kerangka SWOT. Hierarki akan tersusun dalam empat level. Level pertama adalah goal atau tujuan, yaitu keputusan yang dijalankan dalam mengembangkan usaha beras sehat pada CV Pure Cianjur. Level kedua adalah kekuatan, kelemahan, peluang, dan ancaman pada faktor SWOT. Level ketiga adalah subfaktor yaitu hasil dari analisis lingkungan internal dan eksternal perusahaan yang merupakan 
faktor kekuatan, kelemahan, peluang, dan ancaman. Level keempat merupakan alternatif strategi yang didapat dari matriks SWOT.

Rancangan arsitektur strategi pengembangan usaha beras sehat $\mathrm{CV}$ Pure Cianjur merupakan rancangan program kegiatan yang dibuat untuk memberikan gambaran mengenai tahapan-tahapan yang dapat ditempuh demi mewujudkan sasaran di masa depan (Gambar 5). Sumbu X merupakan periode waktu yang digunakan dalam periode tahun, sedangkan sumbu Y merupakan waktu urutan program kegiatan. Terdapat serangkaian program yang di buat berdasarkan strategi pengembangan yang telah dirumuskan pada analisis SWOT. Program ini dibuat sebagai langkah konkrit atau langkah strategis untuk menghadapi tantangan dan mencapai sasaran.

Terdapat dua klasifikasi program yang direkomendasikan untuk mencapai sasaran yang diharapkan, yaitu program yang dilaksanakan secara terus menerus dan program yang dilaksanakan secara bertahap dan terbagi ke dalam empat periode, dan per-periode memiliki jenjang dua tahun yang dimulai dari tahun 2018. Program yang dilaksanakan secara terus menerus akan dilakukan sepanjang tahun pelaksanaan program. Adapun program yang termasuk pada klasifikasi ini ialah: 2a) membuat kontrak kerja (MoU) dengan mitra kerja baru untuk mendapatkan jaminan keberlangsungan kerjasama yang telah dijalin; 2b) menjaga kepercayaan pemasok; 5a) menjaga kepercayaan pelanggan dan mempertahankan kerjasama yang sudah ada dengan pihak distributor, retailer, maupun konsumen; 5b) melakukan grading pada beras sehat yang akan dipasarkan dan membuat segmentasi pasar untuk masing-masing grade; 6b) bekerjasama dengan pemerintah dalam rangka memberikan edukasi mengenai kelebihan dari beras sehat dibandingkan dengan beras anorganik; 8b) membuat brosur dengan penjelasan manfaat dan kelebihan dari beras sehat dibandingkan dengan beras anorganik dalam memasarkan produknya dan 8c) aktif dalam mengikuti pameran produk organik. Sedangkan program yang dilaksanakan secara bertahap akan dilakukan pada waktu tertentu dari rentang waktu yang direncanakan. Adapun program yang termasuk pada periode pertama atau tahun pertama ialah : 1a) melakukan persiapan untuk pendaftaran untuk mendapatkan sertifikasi organik; 1b) memberikan pembinaan bagi petani anggota kelompok tani mitra yaitu Kelompok Tani Bangkit agar bisa memenuhi standar yang ditetapkan oleh lembaga sertifikasi pangan organik; 3b) membuat logo yang lebih menarik perhatian konsumen dengan menggunakan warna-warna yang menarik; dan 5c) mengembangkan produk dengan olahan produk turunannya.

Program yang termasuk pada periode kedua ialah: 3c) membuat rencana untuk membuat merek baru yang lebih mudah diingat dan menarik; dan 4a) membeli alat sortir beras. Program yang termasuk pada periode ketiga ialah : 3a) membuat kemasan dengan dilengkapi kandungan gizi beras sehat dan manfaatnya serta cara untuk memasak; 6a) bekerja sama dengan institusi pendidkan ataupun dengan lembaga pemerintahan serta 
para peneliti untuk melakukan uji kandungan nutrisi dan gizi dari beras sehat bila dibandingkan dengan beras anorganik serta 7a) melakukan negoisasi dan menyusun rencana kerjasama ke depannya dengan petani ataupun kelompok tani yang berpotensi menjadi mitra. Sedangkan program yang termasuk pada peride akhir atau periode keempat ialah : 7b) membuat kontrak kerja (MoU) dengan mitra kerja baru untuk mendapatkan tambahan pasokan bahan baku dan 8a) melakukan kerjasama dengan rumah sakit, hotel, dan restoran serta distributor baru.

Prioritas strategi dalam aplikasi arsitektur startegik dapat membantu manajer dalam memilih program kerja yang akan dilakukan terlebuh dahulu. Prioritas strategi juga dapat diandalkan ketika perusahaan harus memilih program kerja apa yang harus dilakukan terlebih dahulu apabila perusahaan memiliki sumberdaya yang terbatas sehingga tidak dapat menjalankan semua program kerja. Namun karena arsitektur bersifat fleksibel maka, seringkali prioritas strategi juga menjadi kurang penting disebabkan oleh pertimbanganpertimbangan dalam mengalokasikan sumberdaya yang tersedia yang dilihat secara komprehensif.

\section{SIMPULAN DAN SARAN} Simpulan

Kekuatan utama yang dimiliki CV Pure Cianjur adalah produk berkualitas, kelemahan utama diskontinuitas bahan baku, peluang utama adalah SDA yang dimiliki Kabupaten Cianjur, dan ancaman utamanya adalah produk substitusi (beras anorganik atau konvensional).
Prioritas alternatif strategi yang diterapkan pada CV Pure Cianjur dalam mengembangkan usaha beras sehat, mulai dari prioritas pertama sampai kedelapan adalah melakukan persiapan dan pendaftaran untuk mendapatkan sertifikasi organik, melakukan pembinaan dan perluasan areal lahan dengan kelompok tani mitra (Kelompok tani Bangkit), melakukan perbaikan kemasan, logo, dan merek produk untuk meningkatkan dayasaing produk, meningkatkan aset investasi berupa alat sortir beras, mempertahankan kualitas produk dan mengembangkan produk turunan beras organik dengan optimalisasi sumberdaya yang ada pada perusahaan untuk memenangkan persaingan, memberikan edukasi kepada masyarakat mengenai kelebihan dan manfaat beras organik, meningkatkan produksi dengan pendekatan backward integration yaitu dengan membina kelompok tani ataupun petani lain yang berpotensi untuk menjadi mitra dalam rangka menjamin pasokan bahan baku, dan melakukan perluasan jaringan pasar.

Implementasi alternatif strategi dibagi dalam dua kelompok yaitu 11 rekomendasi program yang dijalankan secara bertahap dan 7 program kerja secara rutin.

\section{Saran}

1. Pelaku usaha pengembangan usaha beras sehat yaitu CV Pure Cianjur sebaiknya menjalankan strategi berdasarkan pertimbangan peringkat prioritas, kemampuan untuk menjalankan, waktu yang dibutuhkan serta biaya dan manfaat yang akan di peroleh. 
2. CV Pure Cianjur diharapkan dapat memperkirakan kapabilitas yang dimiliki, pengalokasian sumberdaya untuk implementasi strategi, serta dalam pengimplementasian alternatif strategi dilakukan dengan kerjasama yang baik dan komitmen yang tinggi dari seluruh stakeholder sehingga pencapaian sasaran dan tujuan perusahaan yang efektif dan efisien dapat terwujud.

3. Pemerintah, khususnya Pemerintah Daerah Cianjur dan Dinas Pertanian dan Tanaman Pangan Kabupaten Cianjur hendaknya memberikan fasilitas pembinaan dan permodalan serta pemasaran kepada petani di daerah Cianjur agar mau beralih ke sistem budidaya organik.

\section{DAFTAR PUSTAKA}

Ahmad. 2012. Tren Konsumen Beras Organik Meningkat. https://pertaniansehat.com/read/ 2012/05/28/tren-konsumenberas-organik meningkat.html. Diakses pada 23 Desember 2016.

Agustina T. 2011. Analisis Perilaku Konsumen Beras Organik di Kabupaten Jember. J-SEP 5(3) : 134-152.

[Balitbangtan] Badan Penelitian dan Pengembangan Pertanian. 2010. Peta Potensi Penghematan Pupuk Anorganik dan Pengembangan Pupuk Organik pada Lahan Sawah Indonesia. Jakarta (ID): Badan Penelitian dan Pengembangan Pertanian, Kementerian Pertanian.

[BPS] Badan Pusat Statistik. 2015. Jakarta (ID): Badan Pusat Statistik.

David FR. 2011. Manajemen Strategis. Sunardi D, penerjemah; Wuriarti
P, editor. Jakarta (ID): Penertbit Salemba Empat. Terjemahan dari: Strategic Management Concepts and Cases. Ed ke-12.

[Deptan] Departemen Pertanian. 2005. 4 tahun Go Organic 2010. Jakarta (ID): Dinas Pertanian

[Disperta] Dinas Pertanian Tanaman Pangan dan Hortikultura. 2012. Profil Kabupaten Cianjur. Cianjur (ID): Dinas Pertanian Tanaman Pangan dan Hortikultura

Görener A, Toker K, Uluçay K. 2012. Application of Combined SWOT and AHP: A Case Study for a Manufacturing Firm. Procedia Social and Behavioral Sciences.58 : 1525-1534

[GPO] Gabungan Petani Organik. 2012. Profil Gabungan Petani Organik (GPO) Nyi Sri Kabupaten Cianjur. Cianjur (ID): Gabungan Petani Organik

[IFOAM] International Federation of Organic Agriculture Movements. 2008. The World of Organic Agriculture Statistics \& emerging Trends 2008. Adelaide: International Federation of Organic Agriculture Movements.

Kangas J, Pesonen M, Kurttila M, Kajanus M. 2001. A'WOT: Integrating The AHP With SWOT Analysis. ISAHP 6th. 2001 Agustus 2-4. Berne, Switzerland. Kurttila M, Pesonen M, Kangas J, dan Kajangus M. 2000. Utilizing The Analytic Hierarchy Process (AHP) in SWOT Analysis- A Hybrid Method and Its Application to A Forest- 
certification Case. Forest Policy and Economic 1: 41-52

Lohr L. 2001. "Factors Affecting International Demand and Trade in Organic Food Products," Changing Structure of Global Food Consumption and Trade, Agriculture and Trade Report WRS-01-1, U.S. Department of Agriculture, Economic Research Service, www.ers.usda.gov/publications/ wrs011/wrs011j.pdf

Lohr L. 1998. Implications Of Organic Certification For Market Structure And Trade. Am J Agric Econ 80(5): 1125-1129.

Oreski D. 2012. Strategy Development by Using SWOT - AHP. TEM Journal 1(4) : 283-291

Osuna EE, Aranda A. 2007. Combining SWOT and AHP Techniques For Strategic Planning. ISAHP. 2007 August 2-6. Viña del Mar, Chile. Pearce, J.A. dan Robinson. 2008. Manajemen Strategik: Formulasi, Implementasi dan Pengendalian, Jilid I. Bina Rupa Aksara Edisi 10. Jakarta.

Solihin I. 2012. Manajemen Strategik. Jakarta (ID) : Erlangga

Wheelen TL, Hunger JD. 2008.

Strategic Management and Business Policy : Concept and Cases Edisi 11. New Jersey : Pearso Education Inc

Yoshida DT. 2006. Arsitektur Strategik : Sebuah Solusi Meraih Kemenangan dalam Dunia yang Senantiasa Berubah. Jakarta (ID) : PT Elex Media Komputindo.

Zarei M, Paghaleh MJ. 2011. Strategic Management of Business in Food Industry: By an Integrated Deployment of AHP and
Freeman Model. Business Management Dynamics 1(3): 4752

Zhang Y, Feng L. 2013. Development Assessment Of Leisure Agriculture In Henan Province of China Based On SWOT-AHP Method. Journal of Industrial Engineering and Management 6(2):642-653 


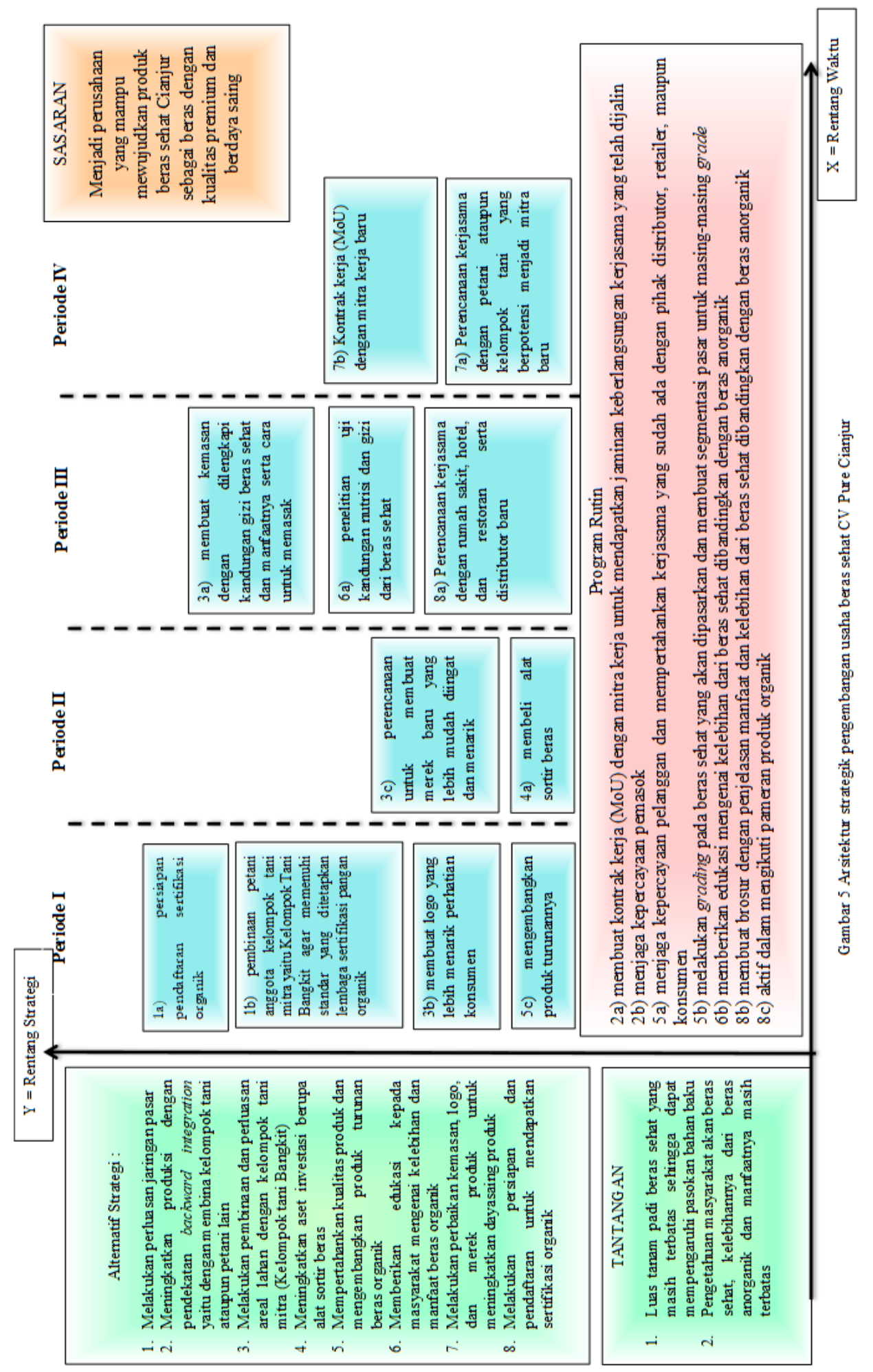


Agrivinie Rainy F, Rita Nurmalina dan Amzul Rifin 
